\title{
Citizenship and Socio-Technical Aspects of Green Supply Chain Management Strategy
}

\author{
Ganesh Vaidyanathan, Indiana University South Bend, gvaidyan.iusb.edu \\ Asghar Sabbaghi, Indiana UniversitySouth Bend, sabbaghi@iusb.edu
}

\begin{abstract}
In this study, we consider green supply chains as a potential area for business growth, product/operation efficiency, and effective utilization of environmental resources. These areas contribute to the greater good of the society. This study intends to focus on the various impacts of the green supply chain in terms of citizenship. We explore the concept of citizenship and how citizenship impacts the supply chain processes. In this study, we discuss the social and technology aspects of business using citizenship as an important factor and its significant impact on business, environmental and social goals for the global community. This paper also aims to differentiate between the various impacts of the green supply chain on the important drivers of green initiative - the suppliers and the customers.
\end{abstract}

Keywords: Citizenship, Socio-Technical, Technology, Social Behaviors, Green Supply Chain Management

\section{INTRODUCTION}

Citizenship in supply chain context is defined by being a member with rights and responsibilities in the supply chain network. We are facing many challenges including impacts from climate changes and rising energy costs. Firms have to exhibit their strong commitment to provide solutions and services to their customers when combating such challenges. Businesses need to provide and adhere to employee and supplier policies for responsible labor practices. They have to meet high ethical standards through their employees and suppliers and involve their customers in their product and service offerings. For example, Hewlett Packard, a global information technology company, has introduced servers that consume up to $89 \%$ less energy and $80 \%$ less space at $77 \%$ less cost. They are committed to reducing the carbon dioxide emissions of their operations by another $20 \%$ by 2020 . Their suppliers are expected to comply with high ethical standards, treat their workforce with dignity and respect. Their customers with long-term contracts are encouraged to include environment, privacy, supply chain responsibility, and other global citizenship factors in their procurement criteria [6]

Firms are under constant scrutiny and are subject to pressures from different segments of society. Their stakeholders have become very conscious of their ecological and ethical performances and standards. The serious message is the rising demand for more environmentally-friendly products by the consumers. Firms have to modify their business strategies with a greater focus on their environmental footprints due to such added pressures and the extra challenges from the consumers. To mitigate this pressure and challenge, many firms are committed to produce clean products in the world and reduce their environmental footprint in every facet of their business. This not only impacts the environment in a positive way but also saves the companies in their energy costs. "Green" or "greening" has become a common practice to represent the value chain and it signifies the ecological standards of business operations, processes, products, systems, technologies, and the general ways by which businesses operate [15]. Green Supply Chain Management (GSCM) has become a new approach that evidences the environmental responsibility and accountability of various firms all over world [15].

Another pressure for the firms has been climate change. Climate change is a strategic dilemma for firms. For example, it affects firms that produce oil and utilities from fossil fuels, firms that use fuels directly to produce chemicals, firms that use fuels directly in transportation, firms that use fuels infirectly to manufacture automobiles and aircrafts, and those who develop market opportunities such as banks and insurance companies. Various companies have started to consider emissions of their supply chain as an action to combat climate change [11]. Many businesses have already taken initiatives to voluntarily comply with climate change mitigation efforts. The main drivers of motivation comes from reducing the impacts of climate change. This reduction can be accomplsihed by cost reduction, brand development, reduction of pressures from environmental grooups, competitiveness, and recognition from customers and stakehoders [4]. However, utilization of voluntary efforts to mitigate climate change 
by green supply chain management strategy have been subject to several criticisms. According to Gerrard [4], green business practices demands an in-depth knowledge of customer requirements and the capability to satisfy those requirements while contributing to ecological sustainability and fulfilling their strategic business goals.

The green supply chain management strategy reflects a social consciousness with respect to saving the natural resources of our Earth and preserving the natural resources for the future generations. Hawken, Lovins, \& Lovins [7] stress the importance of green business strategy by stating that ecological problems are innately social responsibility problems and concerns. They also outlined five strategies for firms to integrate their environmental investments with profitable ventures. It is composed of product differentiation and price increases. It also consists of overcoming their competitors through policy lobbying and regulatory means. Another means is by cost cutting measures, which is also beneficial to the environment. Finally, companies can systemically adapt to the changes imposed by the environmental policies and regulations in their business strategies. These five approaches can make environmental problems more manageable to business leaders and managers. However, these authors also posit that environmental investments should be considered as a long term investment. According to them, establishing sustainable business strategies involve lowering energy and material consumption, reducing burdens of pollution, replenishing depleted resources, and developing clean products and technology. In summary, managers must recognize both social and economic benefits of environmental protection in order to sustain the environment.

In order to reap the benefits of GSCM, firms need to be responsible and display their corporate citizenship. Good corporate citizenship extends the way firms run their business and conduct themselves as individuals. Firms have to focus on creating a culture of citizenship grounded in the foundational elements of sound business practice. Since the sustainability of business and society are interdependent, good citizenship requires creativity and attention when businesses treat customers and suppliers by exhibiting high standards of ethics and compliance.

This research study explores the concept of citizenship in making a powerful impact on GSCM. Specifically, this research aims to answer this fundamental research problem: What is the impact of citizenship on the socio-technical green supply chain management strategy? Aside from the main theme, this paper aims to differentiate between the various impacts of the green supply chain on the important drivers of green initiative - the suppliers and the customers. This will contextualize the effects of the environmental justifications for going green within the perspective of suppliers and consumers.

\section{GSCM AND CITIZENSHIP}

In this study, we consider GSCM as a dimension of a broader framework of corporate sustainability including economic, environmental, and social perspectives. Economic sustainability requires an organization to manage its resources and capital to provide better returns to their shareholders. The environmental sustainability includes lean natural resources to be consumed efficiently by operating firms in order to create desired outcomes. The operating firms do not cause emissions that accumulate in the environment at a rate beyond the capacity of the natural system to absorb and assimilate these emissions as well as not engaging in activities that degrades eco-system services [2]. The social perspective [2] considers the capabilities, the knowledge, the motivation and the loyalty of human resources and societal resources such as educational systems, infrastructure and cultural values. Socially sustainable corporations can be regarded as those that are seen as fair and trustworthy by all stakeholder groups [9].

Corporate citizenship involves strengthening of the social bonds between the company, its employees, and the local community. Citizenship helps a company to build its reputation and therefore increases its capacity to attract contracts and benefits with suppliers and governments, to charge premium prices for its products, and to reduce its cost of capital. It also increases employee morale, attract new employees, and develop potential customers [3]. As shown above, citizenship impacts the supply chain process. Citizenship has footprints in both the social and technical dimensions of GSCM strategy. A recent research study [10] reviews the socio-technical systems theory used in supply chain. The theory provides a framework for understanding social, technical, and environmental aspects of organizational behavior interact to produce outcomes. This is further explored in the following sections. 


\section{SOCIAL DIMENSION OF CITIZENSHIP IN GSCM}

In this section, we illustrate the social aspects of the green supply chain environment from the viewpoints of supplier, company, and customer. Firms have developed social dimensional strategies for better relations with their stakeholders and general public by using company image, product image, and customer satisfaction.

\section{Social Aspects of Citizenship: Company Perspective}

Corporate citizenship programs are aimed to sensitize employees to environmental conditions [8]. Corporate volunteerism and community involvement expose employees to the diverse requirments of local areas and their residents. Tsingtao Brewery Co Ltd, one of China's oldest beer producers, received the Excellence in Environmental Sustainability Award for 2011 after fearing of being "delisted" from award-winning companies. The management explained that they intensified their efforts when they felt the public pressure. This example goes to show how an uncommitted citizenship can shift its gears and focus on managing sustainability as a corporate strategy and tactic against pressure.

Firms enjoy reputation through such citizenship activities and their employees have the highest potential impact. The firms benefit from their employee participation in their citizenship activities and those activities increases the company's appeal in the local area as well as helps them to recruit new hires. For example, Wal-Mart offers parttime income to local senior citizens. Citizenship activities can help companies with a lower cost of capital which will help their investors to look favorably. For example, as many of Ben \& Jerry's investors preferred social responsibility, they were still able to obtain adequate capital [13]. Corporate affiliation with philanthropic and charitable organizations portray a positive corporate image.

Titleist, the golf equipment manufacturer, trains their employees to be responsible in supply chain management. Their employees must comply with the Company's Code of Business Conduct and Ethics, which reflects that child, prison, or forced labor are not permitted at any operation. Many firms have incorporated corporate citizenship, supplier diversity, ethics, labor practices, human rights, conflicts of interest, confidentiality, and privacy in their principles of conduct for their employees.

One another important factor in corporate citizenship is bribery. Firms need to counteract corruption including extortion and bribery. Coca Cola, the leading beverage company, is ommitted to doing business with integrity including the avoidance of corruption in any form and complying with the anti-corruption laws of every country in which they operate [1].

\section{Social Aspects of Citizenship: Supplier Perspective}

The success of a company's green supply chain management strategy is also reliant on the cooperation and integration of their suppliers [15] as suppliers help in providing important ideas implemented in environmental projects. To exemplify, companies like NHS Trust Alpha, Public B, Jojoba and Electroment advocated improved environmental performance to their suppliers. At Jojoba and Electroment, suppliers were expected to join in the evaluation of their environmental footprint and expected full commitment from their suppliers [16].

Citizenship activities can create great opportunities for suppliers to develop and improve mutual trust. Corporate volunteer activities bring together employees of companies and their suppliers. Suppliers can threaten the company's performance and reputation by ending crucial flows of products, services and resources when they defect from companies. The images of Nike and Adidas were tarnished by their suppliers using child labor. Titleist, the golf equipment company, has adopted and implemented a supplier citizenship policy which describes their business practices and employment standards applicable to their worldwide direct suppliers. The policy is aimed to ensure that slavery and human trafficking do not occur in their direct supply chain. The company also makes significant efforts to make sure that forced labor and child labor are not part of their suppliers labor force. They conduct evaluations and screenings of their prospective and existing suppliers. Their suppliers are audited for compliance 
either annually or bi-annually and may even terminate their suppliers if violations are found. Many firms have incorporated corporate citizenship, supplier diversity, ethics, labor practices, human rights, conflicts of interest, confidentiality, and privacy in their principles of conduct for their employees

\section{Social Aspects of Citizenship: Customer Perspective}

Customers provide citizenship behavior for firms as well. Customers drive GSCM in many significant ways. Customers exhibit discretionary behaviors that support the ability of a firm to deliver quality. For example, customers can apply pressure on businesses to seriously consider green supply chain practices. Customers can act as promoters of firms in a voluntary behavior to benefit firms. Loyalty of customers leads to repeat purchases and recommendations. Citizenship activities are very much like advertising and they promote a positive image of the company. Customers also can favor products and services that validate corporate citizenship and can pay a premium price for such products and services.

Customers are also being engaged in the citizenship activities by many companies. Frito-Lay, a division of PepsiCo, Inc., launched a marketing campaign for its Dorito corn chip product. They invited some customers to participate and compete in an advertisement. The winning advertisements were integrated into their actual marketing campaigns [5]. Target, the department store, launched a charity campaign through its Facebook site where they allowed Facebook users to vote for a recipient of their choice to donate one million dollars [12]. This enabled them not only to illustrate their corporate social responsibility but made an impact among their customers. Customer citizenship also includes helping other customers in finding products, helping other with their shopping, providing feedback to customer service, responding to surveys, and informing firms about good and bad employees.

\section{TECHNICAL DIMENSION OF CITIZENSHIP IN GSCM}

Firms are facing challenges in adopting information technology in an environment friendly and a sustainable supply chain network. We understand that information technology plays an important and a crucial part in green supply chain networks. There are various important drivers of information technology that enable GSCM and citizenship in particular. The quantity and quality of information exchanged between the three major players in supply chain network are very important in their collaboration efforts. Sabbaghi and Vaidyanathan [14] laid out a framework within the broader context of corporate sustainability values with information technology as an enabler that would contribute to the three different dimensions of corporate sustainability including economic, environmental, and social values.

\section{Technical Aspects of Citizenship: Company Perspective}

Corporate strategy and governance embraces information technology in GCSM by featuring corporate citizenship behaviors. The technology components include computers, servers, printers, storage devices, networking, and communication systems. In addition to these typical components, data center components include storage devices, uninterruptable power supplies, switches, chillers, air conditioners, pumps, cooling towers, generators, batteries, and lighting have to be considered as well.

The importance of effective IT governance is central to citizenship in corporate GSCM. IT governance improves the alignment between IT strategies and corporate social initiatives of citizenship. IT governance directs and controls organizations to achieve their citizenship goals and is an integral part of organizational governance. It provides support and monitors IT performance to ensure the company's citizenship goals are realized. In day-to-day supply chain operations, technology plays a central theme and the company's applications have an integrated view of all citizenship processes, ethics, and business practices.

\section{Technical Aspects of Citizenship: Supplier Perspective}

Suppliers must have the technological skills needed to adopt new technologies that their customers use. Suppliers are therefore expected to be able to merge their own skills with those of their customers to create a unique technological capability that generates new values. The relationship of operating companies with their suppliers involves rapid and timely exchange as well as sharing of large volumes of information. Such actions enable 
transactions to be performed efficiently and effectively. For example, Sony, the electronics company, employs ecommerce and they require all their suppliers to be compatible with such technology. Suppliers who wish to become Sony partners must have the technological skills needed to adopt and create new technologies that Sony requires and they are expected to be able to merge their own skills with those of Sony to create a unique technological capability that generates new values.

Many suppliers need to have direct connections with operating companies and be integrated with them to be efficient and effective. For high volumes of transactions, suppliers need to be ready to use Electronic Data Interchange (EDI) or Extensible Markup Language (XML) be integrated with their customers. For example, Ariba, the business to business (B2B) collaboration tool company, uses Commerce Extensible Markup Language (cXML). cXML is a protocol that is used for communication of business documents between procurement applications, ecommerce hubs, and suppliers. Firms preselect suppliers based on collected data, profile. They check basic requisites by pre-auditing their potential suppliers. They evaluate those potential suppliers based on technology and process requirements criteria before they choose their suppliers. One of main evaluations of suppliers is their supplier process capability.

\section{Technical Aspects of Citizenship: Customer Perspective}

Technology requirements of customers are varied based on whether a customer is an individual or an organization. The least amount of technology needed by individual customers is the knowledge of the usage of Internet. For the employee of a company who is a customer, the technology needs are different. Employees need to know how to collaborate and communicate electronically, share documents, manage files and folders, and manage large quantity of data. To align with company's technology, employees need to understand company processes and possible use of sophisticated software that involves electronic invoicing and computerized shipping and tracking.

\section{CONCLUSIONS}

Green procurement strategies in terms of citizenship should ideally push suppliers to develop good environmental management practices and comply with specific requirements for enhanced environmental performance to their own group of suppliers. However, this takes time and money. Suppliers do not normally comply unless they have to adopt environmental management as a strategic approach in order to follow the environmental standards or practices demanded by their partner businesses. The impact of citizenship helps firms, suppliers, operating businesses, and customers alike, to be environmentally sustainable and compliant. The supply chain, as a major factor for competitive advantage in most businesses, poses social and technical challenges. The characteristics of a successful and sustainable supply chain must definitely include the social and technology aspects of citizenship as they promote environmental well-being and sustains the future use of the same resources for the next generation.

Social and technology impacts of citizenship that pertains to operating businesses and their suppliers and customers are crucial to the success of businesses, not only in terms of the new management philosophies but also in terms of reduced costs in logistics and operations. The supply chain performance factors include cost, quality, flexibility, and delivery. Green project partnerships with customers are positively linked to quality, flexibility, and environmental performance while partnership with suppliers is associated with better delivery performance [15].

\section{IMPLICATIONS AND FUTURE RESEARCH}

This paper discusses the socio-technical theoretical considerations in citizenship that are important to greening the value chain of business while establishing ethical values. This research extends new insights for practitioners and academicians towards citizenship focused environmental goals for the global business community. Good citizenship practices enforce greater supply chain performances. Corporate citizenship is a strategic tool that companies can use to manage reputation for companies. Such citizenship initiatives enable finer execution of GSCM strategies which in turns enhances performance. Firms need to design and implement those citizenship activities in order to reap performance benefits. Firms need to invest and commit themselves to citizenship activities. Researchers can focus on deeper investigation of citizenship activities and how they can improve corporate GSCM performance. 


\section{REFERENCES}

1. Coca Cola. (2014). Anti-corruption. Accessed on May 11, 2011 from http://www.cocacolacompany.com/our-company/governance-ethics/anti-corruption\#TCCC.

2. Dyllick, T., \& Hockerts, K. (2002). Beyond the business case for corporate sustainability. Business Strategy and the Environment, 11(2), 130-141.

3. Fombrun, C.J., Gardberg, N.A., \& Barnett, M.L. (2000). Opportunity platforms and safety nets: Corporate citizenship and reputational risk. Business \& Society Review, 105(1), 85-106.

4. Gerrard, M. (2007). Global Climate Change and U.S. Law. Washington, D.C.: American Bar Association.

5. Gilde, C., Pace, S., Pervan, S. J., \& Strong, C. (2011). Examining the boundary conditions of customer citizenship behavior: a focus on consumption ritual. Journal of Strategic Marketing, 19(7), 619-631.

6. HP (2012). HP 2012 Global Citizenship Report. Accessed on May 11, 2013 from http://h20195.www2.hp.com/ V2/GetPDF.aspx/c03742928.pdf.

7. Hawken, P., Lovins, A., \& Lovins, L. H. (2008). Natural Capitalism: Creating the Next Industrial Revolution. New York: Back Bay Books.

8. Katz, D. \& Kahn, R.L. (1966). The Social Psychology of Organizations. New York: Wiley.

9. Kaptein M, \& Wempe J. (2001). Sustainability management, balancing conflicting economic, environmental, and social corporate responsibilities. Journal of Corporate Citizenship, 1(2): 91-106.

10. Kull, T. J., Ellis, S. C., \& Narasimhan, R. (2013). Reducing Behavioral Constraints to Supplier Integration: A Socio-Technical Systems Perspective. Journal of Supply Chain Management, 49(1), 64-86.

11. Kolk, A., \& Pinkse, J. (2004). Market Strategies for Climate Change. European Management Journal, 22(3), 304-314.

12. Kaushik, P. (2011). What does the expansion of digital identities mean for the future of online businesses? Accessed on May 11, 2014 from http://www.businessinsider.com/what-does-the-expansion-of-digitalidentities-mean-for-the-future-of-online-businesses-2011-5.

13. Rigby, R. (1998). Tutti Frutti. Management Today, February, 54-56.

14. Sabbaghi, A., \& Vaidyanathan, G. (2012). Green information technology and sustainability: A conceptual taxonomy. Issues in Information Systems, 13(2), 26-32.

15. Vachon, S. \& Klassen, R. D. (2006). Extending green practices across the supply chain: the impact of upstream and downstream integration. International Journal of Operations \& Production Management, 26(7), 795-821.

16. Walker, H., Di Sisto, L., \& McBain, D. (2008). Drivers and barriers to environmental supply chain management practices: Lessons from the public and private sectors. Journal of Purchasing \& Supply Management, 14, 69-85. 